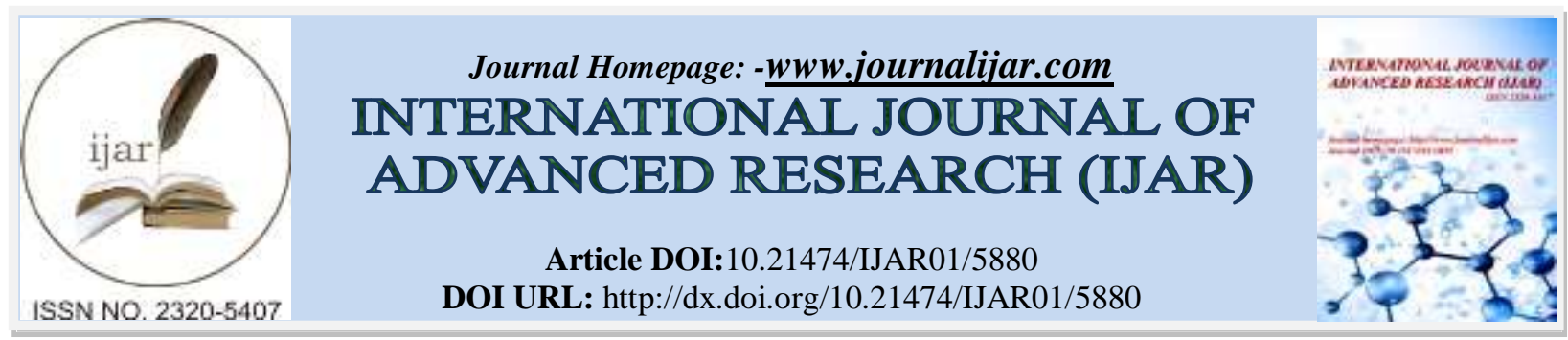

RESEARCH ARTICLE

\title{
EMPIRICAL STUDY ON AGRO-BASED INDUSTRIAL ECONOMY OF DIMAPUR DISTRICT OF NAGALAND, INDIA.
}

Tiatemsu Jamir, Aatish Kumar Sahu and Sanjoy Das.

Department of Agricultural Economics, SASRD, Nagaland University, Medziphema, Nagaland.

\section{Manuscript Info}

Manuscript History

Received: 16 September 2017

Final Accepted: 18 October 2017

Published: November 2017

Key words:-

Agro-industry, MSME, clustered industry, SHGs, co-operatives, food processing.

\begin{abstract}
In modern world, industrial economy is an important part of any developing state. The current study is based on understanding agrobased industry in Dimapur district of Nagaland. Nagaland state of India is hilly region, sparse population and primarily agricultural (horticulture) economy and having an infant industry sector. Dimapur district was purposively selected as it being the commercial capital of Nagaland with a sample of 20 agro-based units classified into five product based classifications viz., Manufacturing Food items, Food processing, Bakery items, Aromatic oils \& Tea and FMCG based on farm inputs. The study identified 144 agro-based units out of about 600 industrial units in the district. More than $80 \%$ of the industries belonged to micro industry having capital expenditure at Rs. 6.85 lakhs and annual turnover of less than Rs. 50 lakhs. The estimated annual economy of agro-based units of the district was Rs. 60.35 crores and total direct employment was 1760 in 2015-16. Three quarters of units had registered their product and quality certification from different certifying agencies. It was observed that cluster based approach in town areas helped in accessing cheaper, sufficient and regular raw materials to getting finance. Also, Self Help Groups in rural and remote locations were identified for growth and development of agro-based industry of the state. However, multiple constraints affecting agro-industry were electricity, raw materials, poor roads and illegal tax system.
\end{abstract}

Copy Right, IJAR, 2017,. All rights reserved.

\section{Introduction:-}

Agro-based industry is the industry that deals with the supply, processing, value addition and distribution of agricultural farm and allied products. As per Nogales (2010) in UN FAO report observed clustering in the agricultural sector helps in creating an enabling environment enhances inter-firm cooperation, supports diffusion of innovations thereby increasing competitiveness in the agricultural sector. It also confirms benefit accrued to farmers and small-scale firms by participation in such clusters, because of joint-action advantages and agglomeration economies. Bio-based Industries Consortium (BBI) in Europe has estimated annual turnover of 2.1 trillion Euro from agriculture and allied industry sector for 2015-16 and regarded Public-Private model as appropriate for sustainable growth and development of European economy. 
Nagaland is $16^{\text {th }}$ state of Indian Union located in north east region of the country comprising of about 1300 villages scattered with sparse population across hilly terrains. It is primarily an agrarian state with high potential of horticultural crops. The principal crops include rice, corn, millets, pulses, tobacco, oilseeds, sugarcane, potatoes, and fibers. Other significant economic activity includes forestry, tourism, real estate, and miscellaneous cottage industries etc. The state Gross State Domestic Product (GSDP) was Rupees 0.18 lakh crore ( $\$ 2.7$ billion dollars) during 2014-15, and was growing at the rate of $6.2 \%$ for the same year (Table 1). Industry or the secondary sector of state economy was meager with less than $2 \%$ contribution from manufacturing.

Dimapur is commercial capital of Nagaland and also the most industrially active district of the state. Its location advantage with respect to National Highway, Railway station and Airport makes the district at par with many developed cities in the country. Rivers like Dhansiri and Chathe crosses through the city and make the city livable. Reports from Government institutions like Central Statistical Organization (CSO) and Ministry of Micro, Small and Medium Enterprises (MSME), popular newspaper articles pertaining to industrial status published etc. has been considered as secondary sources for studying agro based industry in the district. Reddy and Kumari (2014) observed the prospects in agro-based industry and noted an increase of merely $0.38 \%$ in total units from 28,584 in 2006-07 to 30,514 in 2011-12 in India. The Compound Growth Rate (CGR) was 5.10 per cent for both beverages and dairy products, and it was 0.48 per cent for manufacture of other food products category in the country (Reddy and Kumari, 2014). Many constraints that plagued agro-based industry were low productivity, losses and other localized issues (Bhat, 2009; Chadha and Sahu, 2003; Dhiman and Rani, 2011). Sinha and Sinha (1992) identified poor horticultural base, a weak production system, market limitations, consumer preferences and government policies as major constraints. The objective of the study was to estimate and characterize agro-based industrial economy in Dimapur district.

\section{Materials and Methods:-}

The study was conducted in Dimapur district of Nagaland based on the information collected during 2015-16 and both primary and secondary data were used. The district was purposively chosen as it is the commercial capital of Nagaland and it has the highest number of agro-based industries in the state. For empirical study, respondents were purposively selected from 20 selected agro based industries from Dimapur district using structured interview schedule. Respondents were the proprietor or managerial staff of the companies, as well as two non- managerial or workers of each of the company. Since the agro-based industries in Nagaland are divergent, scattered and few in numbers, some established Self Help Groups (SHGs) working on production of some agricultural input based products were also involved in the study. Various study parameters were tabulated, summarized and were subjected to statistical analysis using t-test for single mean for significance and using frequency chi-square test (Contingency Table) for studying association of attributes.

Table 1:-Gross State Domestic Product (GSDP) of Nagaland and contribution from agro-based industry at constant price (2004-05)

\begin{tabular}{|c|c|c|c|}
\hline Year & $\begin{array}{c}\text { GSDP (Rs. lakhs) Agri. \& } \\
\text { allied }\end{array}$ & $\begin{array}{c}\text { GSDP (Rs. lakhs) } \\
\text { Manufacturing }\end{array}$ & Total GSDP (Rs. lakhs) \\
\hline $2009-10$ & $233878(27.64 \%)$ & $21105(2.49 \%)$ & 846258 \\
\hline $2010-11$ & $253538(27.41 \%)$ & $16293(1.76 \%)$ & 925399 \\
\hline $2011-12$ & $267043(26.64 \%)$ & $17814(1.78 \%)$ & 1002385 \\
\hline
\end{tabular}

Parenthesis is percentage to total GSDP, Source: Statistical Handbook of Nagaland (2014)

Table 2:-Industrial units, capital expenditure and employment in Nagaland in 2013

\begin{tabular}{|l|l|c|}
\hline \multicolumn{1}{|c|}{ Sl. No. } & \multicolumn{1}{|c|}{ Particulars } & Frequency \\
\hline 1. & No. of working units & $534(47.94 \%)$ \\
\hline 2. & No. of closed units & $580(52.06 \%)$ \\
\hline 3. & Total employment & 4803 \\
\hline 4. & Employment per unit & 9 \\
\hline 5. & Fixed investment per unit (Rs. in lakhs) & 7.76 \\
\hline
\end{tabular}

(Source: Statistical Handbook of Nagaland, 2013) 
Table 3:-Registered industrial units and employment in Dimapur district

\begin{tabular}{|l|c|c|}
\hline Year & No. of Registered Units & Employment \\
\hline $2010-11$ & 210 & 1050 \\
\hline $2011-12$ & 127 & 635 \\
\hline $2012-13$ & 148 & 740 \\
\hline $2013-14$ & 66 & 568 \\
\hline $2014-15$ (upto Jan 2015) & 51 & 454 \\
\hline Total & 602 & 3447 \\
\hline
\end{tabular}

Source: MSME report, Dimapur (2015)

Table 4:-Micro and Small Enterprises (MSE) in Dimapur district

\begin{tabular}{|l|l|l|l|}
\hline \multicolumn{1}{|c|}{ Sl. No. } & \multicolumn{1}{|c|}{ Head } & \multicolumn{1}{|c|}{ Unit } & \multicolumn{1}{|c|}{ Particular } \\
\hline 1 & Registered Industrial Unit & MSE sector & 575 \\
\hline 2 & Registered Medium and Large & Numbers & 12 \\
\hline 3 & $\begin{array}{l}\text { Estimated average number of daily workers employed in small } \\
\text { scale industries }\end{array}$ & Numbers & 1250 \\
\hline 4 & Employment in Large and Medium industries & Numbers & 150 \\
\hline 5 & Number of industrial area & Numbers & 4 \\
\hline 6 & Turnover of Small Scale industries & In Rs. Lakhs & 4.50 \\
\hline 7 & Turnover of Medium and Large Scale industries & In Rs. Lakhs & 10.50 \\
\hline
\end{tabular}

(Source: MSME report, 2015)

Table 5:-MSME details of agro-based industries of Dimapur (2010-13)

\begin{tabular}{|l|l|l|l|}
\hline Industry type & $2010-11$ & $2012-13$ & Change \\
\hline Food Prod. and Beverage & 15 & 15 & nil \\
\hline Manufacturing of weaving apparels & 34 & 34 & nil \\
\hline Leather works & 1 & 1 & nil \\
\hline Manufacturing of rubber and plastic & 19 & 19 & nil \\
\hline Manufacturing of furniture & 68 & 68 & nil \\
\hline Citronella Farm & 1 & 1 & nil \\
\hline Lemon grass distillation & 5 & 4 & $(-20 \%)$ \\
\hline Citronella distillation & 0 & 1 & $100 \%$ \\
\hline Patchouli distillation & 1 & 1 & nil \\
\hline
\end{tabular}

(Source: Statistical Handbook of Nagaland, 2013)

Table 6:-Classification of sample industry based on product category

\begin{tabular}{|c|c|c|c|}
\hline Product category & Description & No. of units & Employment \\
\hline Manufacturing Food items & $\begin{array}{c}\text { Milling, packaging, dairy items, } \\
\text { noodles }\end{array}$ & 3 \\
\hline Food processing & Beverages, squash drinks, pickling & 9 & 117 \\
\hline Bakery items & Breads and oven food items & 3 & 29 \\
\hline Aromatic oils \& Tea & Citronella, fragrance, Tea & 3 & 61 \\
\hline FMCG based on farm inputs & Soaps, detergents & 2 & 19 \\
\hline Overall & & 20 & 287 \\
\hline
\end{tabular}

Table 7:-Brief findings of the sample agro-based units $(n=20)$

\begin{tabular}{|l|l|l|}
\hline \multicolumn{1}{|c|}{ Sl. No. } & \multicolumn{1}{|c|}{ Character of sample industry } & \multicolumn{1}{|c|}{ Frequency $(\%)$} \\
\hline 1 & Micro industry & $16(80)$ \\
\hline 2 & Food processing industry & $10(50)$ \\
\hline 3 & Manufacturing food industry & $6(30)$ \\
\hline 4 & Single proprietorship & $13(65)$ \\
\hline 5 & Co-operatives owned units and Self Help Groups & $6(30)$ \\
\hline 6 & Average direct employment & 14 persons \\
\hline 7 & Range of products (more than 1) & $18(90)$ \\
\hline
\end{tabular}




\begin{tabular}{|l|l|l|}
\hline 8 & Storage structure and Warehouses (at least one) & $17(85)$ \\
\hline 9 & Spoilage losses (at least Rs. 1 lakh per year) & $15(75)$ \\
\hline 10 & Product quality certification & $15(75)$ \\
\hline 11 & Female managers & $11(55)$ \\
\hline 12 & Managers with Graduation degree & $13(65)$ \\
\hline
\end{tabular}

Table 8:-Chi-square test on association of attributes of agro-based industry

\begin{tabular}{|l|l|}
\hline \multicolumn{1}{|c|}{ Bi-variate associations } & \multicolumn{1}{c|}{ Chi-square probability } \\
\hline Gender vs salary of workers & $0.058^{*}$ \\
\hline Age of Manager vs Annual revenue & 0.124 \\
\hline Category vs Product Mix & 0.379 \\
\hline Staff Strength vs Annual Revenue & 0.303 \\
\hline Qualification vs Skill set of workers & 0.123 \\
\hline Skill set vs Idea sharing of workers & 0.196 \\
\hline Working time vs Migrated workers & $0.022^{* *}$ \\
\hline Migrated workers vs Medical facilities & 0.577 \\
\hline Migrated workers vs Financial support & 0.277 \\
\hline
\end{tabular}

* Significant at $\mathrm{p}=0.10$

** Significant at $\mathrm{p}=0.05$

Table 9:- Dimensions of agro-based industry and its significance

\begin{tabular}{|l|l|l|}
\hline Particulars & t-value & t-probability \\
\hline $\begin{array}{l}\text { Perception of Managers on Government support (Null hypothesis } \mathrm{H}_{0} \text { : Perception } \\
=\text { "Low/ adequate") }\end{array}$ & -4.27 & $\begin{array}{l}0.00^{* *} \\
(19 \text { d.f.) }\end{array}$ \\
\hline $\begin{array}{l}\text { Quality certification by companies (Null hypothesis } \mathrm{H}_{0} \text { : No. of companies } \\
\text { having no certifying agencies) }\end{array}$ & 6.16 & $\begin{array}{l}0.00^{* *} \\
(19 \text { d.f.) }\end{array}$ \\
\hline $\begin{array}{l}\text { Future perception of agro-based industry felt by workers (Null hypothesis } \mathrm{H}_{0}: \\
\text { Perception } \leq \text { "Good") }\end{array}$ & 12.60 & $\begin{array}{l}0.00^{* *} \\
(39 \text { d.f. })\end{array}$ \\
\hline Average losses per worker per year (Null hypothesis $\mathrm{H}_{0}$ : Losses $\leq$ Rs.5000) & 2.17 & $\begin{array}{l}0.021^{*} \\
(19 \text { d.f.) }\end{array}$ \\
\hline
\end{tabular}

* Significant at $\mathrm{p}=0.05 * *$ Significant at $\mathrm{p}=0.01$

Table 10:-Characterization of agro based industry in Nagaland

\begin{tabular}{|l|l|l|}
\hline Sl. No. & Character of industry and market & Remarks \\
\hline 1 & Low capital investment to set up agro-based units & $\begin{array}{l}\text { Capital expenditure less than Rs. 10 lakhs are } \\
\text { feasible for setting up a agro-based unit, since } \\
\text { large units are economically infeasible. }\end{array}$ \\
\hline 2 & Untapped organized food and beverages market & $\begin{array}{l}\text { Organized food market is negligible in } \\
\text { Nagaland, hence opportunity lies. }\end{array}$ \\
\hline 3 & Availability of agricultural raw materials & Supply is erratic and seasonal. \\
\hline 4 & Cluster industry* & $\begin{array}{l}\text { Conducive to this region, however regulation } \\
\text { and support needed. }\end{array}$ \\
\hline 5 & Self Help Groups based industry & $\begin{array}{l}\text { Many SHGs are using locally available agro- } \\
\text { inputs for value addition; important women } \\
\text { empowering units }\end{array}$ \\
\hline
\end{tabular}

Table 11:-Constraints faced by agro-based units in Dimapur ( $\mathrm{n}=20)$

\begin{tabular}{|l|l|c|}
\hline Sl. No. & Nature of Constraints & Frequency (\%) \\
\hline 1 & Irregular and poor electricity supply & $18(90)$ \\
\hline 2 & Procurement of raw materials & $15(75)$ \\
\hline 3 & Transportation & $16(80)$ \\
\hline 4 & Lack of marketing facilities/ market & $12(60)$ \\
\hline 5 & Lack of Government initiative & $10(50)$ \\
\hline 6 & 'Illegal Taxation' & $15(75)$ \\
\hline
\end{tabular}




\section{Results and Discussion:-}

Reports on status of industrial units in Nagaland showed an abysmal performance that more than $52 \%$ of total units were closed due to various reasons during 2011-12 (Table 2 and 3). It was observed that per unit fixed investment was Rs. 7.76 lakhs and employment per unit was nine, which represents the availability of micro and small enterprises in the state.

In Dimapur, NIDC (Nagaland Industrial Development Corporation) was facilitating the growth of small scale and cottage industries in the district. Some other institutions, training centre and emporiums were also visible in the district to look after the industrial growth in the region. As per MSME report 2014-15, Dimapur district had 59 units of trade-wise registered MSME (Ministry of Micro Small and Medium Enterprises) during 2013-14 out of which 23 were agro based and textile enterprises representing 39 percent of all units registered, and in Kohima district there were 33 registered enterprises out of which 20 being agro-based.

The detail reports on growth of Micro, Small and Medium Enterprises in Dimapur district for the year 2009-10 to 2012-13 showed 'nil' and negative growth in agro-based units (Table 5). There were 36 farms of Citronella and Medicinal/Aromatic plants under Industries and Commerce Department in Nagaland in 2013-14.

As per the report (MSME, 2015), there were four major manufacturing clusters in Dimapur district viz. Handloom cluster at Dhansiripar; Export Park at Ganeshnagar; Old \& New Industrial Area, Dimapur and MIC Tuluvi area. Some of the clusters were Cement craft cluster (25 units), Cane \& Bamboo cluster (25 units) at Chumukedima, Steel fabrication cluster (25 units) at Purana Bazar, Tea processing cluster, Stone crushing cluster at Chumukedima (25 units), Food Processing cluster (15 units) at Padampukhuri and Handloom cluster (20 units) at Nagarjan area. The cluster approach was helpful for micro and small units for sourcing raw materials, marketing of finished goods as well as it gave the buyers a better deal for manufactured items in respect to quality and price. Also managing a homogenous type of cluster was much easier than different units spread apart at different locations.

Major exportable items from the district were Naga chili, Ginger, Soya bean, Bamboo products, cane products, pets products, etc. Industrial growth was recorded in hand loom, food processing, printing, various bamboo and wood based works and prioritized by Government which earmarked Ganesnagar area of Dimapur as centre of ancillary units. These ancillary units may help in setting up heavy and large scale enterprises in and around Dimapur city. Following aspects pertaining to industrial development in Dimapur district (Table 4) were identified:

1. Out of 575 industrial units during 2015, about 144 units were agro-based units.

2. Growth of registered units in the district was significantly dropped over years representing negative growth indicating lower growth of employment in industrial units.

3. Average annual turnover of all micro and small industrial units during 2015 was Rs. 4.5 lakhs, whereas for medium and large industries in the district was Rs. 10.5 lakhs.

4. Fixed capital investment per industrial unit was Rs. 7.76 lakhs during 2011-12 (Table 2) and average employment per unit was only 9. For agro-based units it was Rs. 6.85 lakhs in 2015 and per unit employment was same with industrial units.

The sample survey conducted under present study comprised of 20 purposively selected agro based units in and around the Dimapur town. The processed food based units were 17 units and the rest were from non-food units (Table 6). Also, it was observed that four Self Help Groups (SHGs) under study were involved in multiple products and there were two co-operative units which focused on specific products only (Table 6). Thus, it is imperative to consider Co-operatives and SHGs present at every remote villages as backbone of industrial development in the district affecting grass root lives. Also many units were managed by females (Table 7) which categorically emphasizes on gender neutrality in agro-based industry that dwells well for the region. As per Sharma et al. (2014), SHGs help women empowerment and livelihood security especially for grass root rural population. The current study emboldens that finding that gender neutral and inclusive growth in agriculture as well as prime agro based industrial lies in working of women based Self Help Groups.

The total fixed capital investment for large and medium industry in Dimapur district was estimated to be Rs. 10.5 lakhs (table 4), however annual revenue of two medium agro based industry was calculated as Rs. 13 crores at current prices of 2015. Similarly, the survey involved two small sized agro-based units with annual revenue ranging between Rs. 50 lakhs to Rs. 5 crores, thus the total turnover of all small sized agro-based units (10 units) was estimated to be Rs. 13.35 crores, and for all micro sized companies with annual revenue ranging up to Rs. 50 lakhs, 
the total revenue was estimated to be Rs. 34 crores (132 units). Overall annual revenue from agro-based industry during 2014-15 was estimated to be about Rs. 60.35 crores.

All the companies were found to belong to one or more association viz. Dimapur Chamber of Commerce, Flour Mill Association etc (table 7). Most of the companies had certification from FSSAI (Food Safety Standard Authority of India) for their products, while some had certification from ISO (International Organization for Standardization). The study also revealed that about 50 percent of the workers worked for about 8 hours per day and 50 percent of the workers worked for more than eight hours per day with due compensation for over-time. The study also found out that about 57.5 percent of the worker's monthly salary was in the range of Rs 6,000-10,000 followed by 32.5 percent in 'less than Rs 6,000' and 10 percent of the workers with salary of 'more than Rs 10,000'. Nearly 43 percent of the workers were skill while unskilled workers constituted about 57.5 percent of the total workers. Most of the skilled workers were found to be machine and equipment operators. It was also found that 62.5 percent of the workers were local and 37.5 percent of the workers were from other States of India.

Test for association of attributes, statistical analysis like frequency chi-square test has been performed at $10 \%$ level of significance (Table 8). The result showed 'gender of workers' and 'monthly salary of workers' were observed to be significantly associated at $\mathrm{p}=0.058$, and about 6 of 11 female workers reported less than category 1 income per month (Rs. 6000) whereas 20 out of 27 male workers reporting category 2 income (Rs. 6000-10000). Also, it was observed here that migrated workers (non-local) with working time significantly higher than local peers $(\mathrm{p}=0.022)$. Multi-dimensions of industrial development parameters were tested statistically using t-test (Table 8). It showed that perception of managers towards "Government support to industry" was significant at $99 \%$ confidence level. Nearly $10 \%$ of the company felt that no support was given to them by the Government and $55 \%$ felt that the support was "very low". Regarding quality certification of the products by companies, the test showed that significant number of companies $(\mathrm{p}=0.00$ ) were having one or more certificates which shows awareness and adoption of quality enhancing skills and technology by the sector. Workers of sample companies had a significant positive perception (atleast "Good") towards future of agro-based industry ( $\mathrm{P}=0.00)$. However annual losses incurred by companies was significantly on higher side $(\mathrm{p}=0.021)$ with losses per worker per year at Rs. 5000 or more.

It is evident that industry and manufacturing is in infancy in the state and future prospect lies in agro-based industry given that more than a quarter of economy comes from agriculture and allied primary sector of economy.

Cluster industry: The agro-based units are getting organized in form of small clusters comprising 15-20 units in Dimapur district. This approach was encouraged by government, supply of raw material and support services, skilled labor gets attracted to clusters, credit by banks becomes hassle free, trainings, subsidies and incentives from government based institutes is faster and effective. The tea based cluster and food processing cluster however young in existence in Dimapur gave a gainful insight into its operation and effectiveness. The study reflects Nogales (2010) and Silva and Mhlanga (2013) supporting clustering in the agricultural sector and use of local inputs and institutions for better environment for growth and development of industrial sector. Agro-based industry in general faces many problems relating to market, raw materials, transportation, financial problems, infrastructure problems, technical problems among others. The study also found similar constraints identified by Sinha and Sinha (1992) and table 12 is brief discussion on same. Illegal taxation by multiple insurgent groups and non-government bodies has been a major challenge for operation of industry or business units in Dimapur.

\section{Conclusion:-}

The study showed that status of agro-based industry in Nagaland is in its infancy and a lot of prospects lie ahead. Two unique characters of the industry were identified: Self Help Groups in remote village areas were working as small agro-based units and empowering lives of women of Nagaland; and Cluster based industry has been considered as torch bearer of better industrial prospect in and around towns and cities of Nagaland. Value addition on farm based and forest based produces at village level needs to be linked through SHGs and co-operatives to respective clusters at nearby towns and cities for capacity building, further value addition, advertising and marketing strategies. With better infrastructure and skilled human resource, the state could leap bound to industrial map of the country and gateway to South East Asia. Poor road, electricity and illegal tax demands from insurgent groups were identified to be causing great harm to development of the society and industrial growth of the state. 


\section{Acknowledgement:-}

The study is a part of unpublished M.Sc. (Ag.) dissertation work and it was fruitful because of efforts of company respondents, SHGs and cooperatives and NIDC, Dimapur, DES, Government of Nagaland, Kohima, Department of Industries and Commerce, Government of Nagaland. We acknowledge their valuable contribution.

\section{References:-}

1. Anonymous. 2015. Brief Industrial profile of Dimapur district, MSME Report, MSME Development Institute, Government of India.

2. Anonymous 2013. Statistical Handbook of Nagaland, Department of Economics and Statistics, Government of Nagaland

3. Anonymous 2014. Statistical Handbook of Nagaland, Department of Economics and Statistics, Government of Nagaland

4. Bhat, S I. 2009. 'Problems and prospects of food processing industry in Western Karnataka.' Unpublished PhD thesis submitted to Shivaji University, Kolapur.

5. ChadhaGKand Sahu P.P. 2003. Small Scale Agro-Industry in India: Low Productivity is its Achilles ' Heel, Indian Journal of Agricultural Economics, Vo1.58, No.3, Pp. 518-543.

6. Dhiman, D. P., and Rani, M. A. 2011, "Problems and prospects of small scale agro based industries: an analysis of Patiala district", International Journal of Multidisciplinary Research, Vol.1 (4), Pp. 14-24.

7. Konig, G, Silva, C. A. D. and Mhlanga, N. 2013. Enabling environments for agribusiness and agro-industries development, United Nation Food and Agricultural Organization FAO report, Agribusiness and Food Industries Series. Rome, Italy.

8. Nogales, E. G. 2010. Agro-based clusters in developing countries: staying competitive in a globalized economy, Agricultural Management, Marketing and Finance Occasional Paper, United Nation Food and Agriculture Organization, Rome, Italy.

9. Reddy and Kumari. 2014. Performance of Agro-Based Industries in India: A Critical Analysis, IOSR Journal of Economics and Finance (IOSR-JEF) Pp. 15-25

10. Rai, K.N, Karwasra, J.C. and Singh, S.P. 1996. Status and potential of Agro-processing industries in Haryana, Indian Journal of Agricultural Marketing. Vol.10 (1), 11-19.

11. Sinha Sanjay and SinhaSaurabh 1992. Small scale fruit and vegetable processing dynamics of development. Economics and Political Weekly, Pp. A93-A99

12. Sharma, N., Wason, M., Singh, P., Padaria, R.N., Sangeetha, V. and Kumar, N. 2014. Effectiveness of SHGs in Improving Livelihood Security and Gender Empowerment, Economic Affairs: Vol. 59 (Special Issue) Pp. 747756.

13. Varghees, K.A. 2006. Prospects and problems of agro processing industries in Bikaner district of Rajasthan. Indian Journal of Agriculture Marketing Vol. 20(1) Pp.124- 130. 